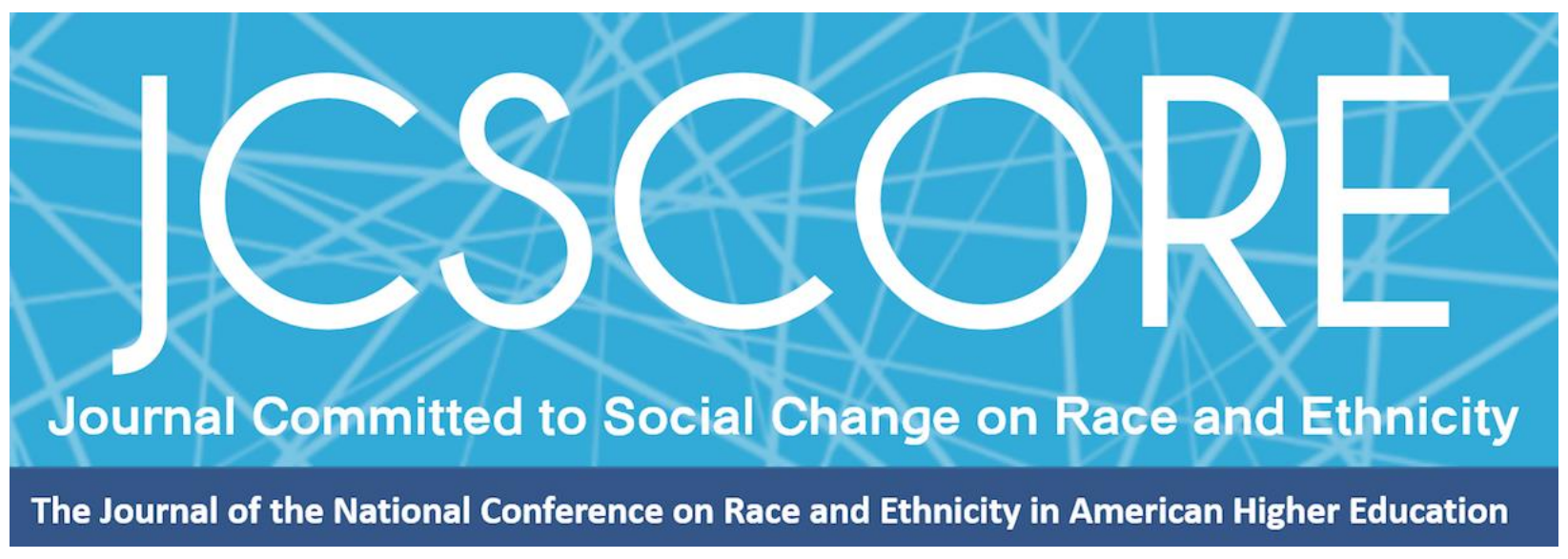

\title{
IN PRAXIS: CREATING A (WEB)SITE OF RESISTANCE AND DISRUPTING THE HIDDEN CURRICULA OF ACADEMIC SOCIALIZATION
}

Katherine S. Cho

Miami University

Journal Committed to Social Change on Race and Ethnicity Volume 7, Issue 2 | 2021

\section{Copyright and Open Access}

(c) 2021 Katherine S. Cho

\section{c) (i) (2)}

This work is licensed under a Creative Commons Attribution-NonCommercial-ShareAlike 4.0 International License. Permission of the authors is required for distribution and for all derivative works, including compilations and translations. Quoting small sections of text is allowed as long as there is appropriate attribution and the article is used for non-commercial purposes.

The Journal Committed to Social Change on Race and Ethnicity (ISSN 2642-2387) is published by the National Conference on Race and Ethnicity (NCORE), a production of the University of Oklahoma, in partnership with the University of Oklahoma Libraries. 
Journal Committed to Social Change on Race and Ethnicity | Volume 7, Issue 2 | 2021

\section{In Praxis: Creating a (Web)Site of Resistance and Disrupting the Hidden Curricula of Academic Socialization}

Katherine S. Cho Miami University

The navigation and socialization within academia is rife with toxicity and a hidden curricula reflective of neoliberal competitiveness, drawn from White cis-hetero colonialist patriarchy. To challenge and resist the toxicity within academia, Communities of Color have created counterspaces to share resources, build beyond the purported individualism, and connect through vulnerability and care. Within this reflection, are the lessons learned of creating one such counterspace through the development of a website-a "site" of resistance.

It started as letters to my students. In 2016, I was in the process of leaving a fulltime position in student affairs and moving across the country to start my doctoral program. With the announcement and subsequent transition, my students and I joked, laughed, and strategized on how we could still do advising. In addition to "academic" mentorship, advising was also made up of moments where my students could feel seen and could have raw conversations about things like imposter phenomenon, navigating immigrant parental pressures, challenges of being first-generation, and dealing with racism and policing both on and off campus. We decided to make a website of sorts, where I could write out the advice I would have shared, had I stayed in West Harlem, New York City. In the coming months, I posted tips and advice for professional development, how to craft a resume, what to consider when applying to graduate school, along with reflections about the bicoastal move to Los Angeles. While continuing to create these posts for my undergraduate students, I slowly integrated letters for the younger version of myself, a doctoral student learning about academia. This website 
Journal Committed to Social Change on Race and Ethnicity | Volume 7, Issue 2 | 2021

transitioned from being a mechanism to stay in touch with my students, into a place to support myself and emerging scholars. In short, it became a place to support us.

Several years and a doctorate later, I can name what we created: a digital counterspace for ourselves within the larger landscape of higher education that consistently messages to marginalized communities that they/we do not belong (see Gildersleeve et al., 2011; Sanchez et al., 2020; Steele, 2018; Yao et al., 2019). From experiences of microaggressions to deficit narratives to even the critique of me-search and doubts of rigor regarding research design (see Delgado Bernal \& Villapando, 2010; Stanley, 2007), scholars have long described how academic socialization and toxicity specifically and disproportionately impacts racially marginalized students, faculty, and practitioners. Communities, especially Communities of Color, have created counterspaces for survival (Ong et al., 2018; Yosso, 2006)— physical and virtual— that represent connections, healing, knowledge spaces, generational wisdom, and a shared belonging (Mac et al., 2021; Tichavakunda, 2020). Within academic navigation, these types of counterspaces offer not only mentorship, but a (re)humanization against the disembodied pressure to produce and push through. In what follows, I offer a reflection on how the "letters" to my students turned into the development of a website and digital counterspace, weaving in its purpose and goals, lessons learned, and implications for praxis.

\section{Evolving a Website}

Higher education institutions, the field of academia at-large, remains rooted in white supremacy, coloniality, capitalism, hetero-cis-gender patriarchy, with a continued proclivity to rebrand itself rather than address the rotted foundations of its core. In doing 
Journal Committed to Social Change on Race and Ethnicity | Volume 7, Issue 2 | 2021

so, the onus remains placed on an individual level (Ahmed, 2012, 2021) where success and excellence are celebrated, absent of the larger systemic and structural critiques in which our navigations exist. Academic publication processes reward and encourage solo submission over collaborations, purporting a myth of the independent scholar (Harris, 2016; Sullivan, 1994). Collaborators must parse out percentages of contribution and authorship order - all of which reinforce individualism, potentially abusive power dynamics, neoliberal logics, and gatekeeping (Patel, 2016). As such, the toxicity of academia encourages against the communal, with incentive towards competition viewing opportunities and knowledge as resources of scarcity, as property to colonially claim and hoard (Patel, 2016; Sarnecka, 2019).

The purpose, goals, and evolution of my website (www.katscho.com) reflects a growth in my own resistance and response to academic socialization. When first starting out the letters to my students, I knew little of the aforementioned concepts and instead, grounded the content in my educational experiences of consistently feeling a beat behind and not belonging. As a Korean American daughter of immigrants, I faced interpersonal and structural gendered racism, which included assumptions about my (lack of) English skills and microaggressions, reflective of the research on Asian Americans being viewed as perpetual foreigners (see Lee et al., 2009). Despite coming from a family of educators, I missed almost every deadline related to college, incorrectly filed for financial aid (FAFSA), and struggled with navigating the bureaucracy of a predominantly white university. As a doctoral student, I still felt a beat behind, unsure of how to find the opportunities to which to apply, conferences to attend, and continued to grapple with the forms of systemic oppression (e.g., racism) that disproportionately 
Journal Committed to Social Change on Race and Ethnicity | Volume 7, Issue 2 | 2021

impacts Students of Color (see Gildersleeve et al., 2011; Patrón et al., 2021), that is further magnified at the intersections of gender, class, immigration status, sexuality, and ableism.

These experiences concretized the first goal of this site: developing resources to navigate academia. While these first started because of how I wanted to support my students, I also realized that the resources I had crafted for myself, could also serve as support. The advice and tips then included the notes I had saved about the difference between a conference paper and class paper; strategies for how to disseminate an article once published; and lessons learned from creating several virtual writing groups, both before and during the COVID-19 pandemic. I shared my running list of fellowships, conference opportunities, and organizational deadlines. From bullet journal layouts for weekly and monthly plans, to GoogleSheets and platforms like Notion, I digitized what I had been using for people to be able to duplicate ways to "organize the academic job search" and "create a semester plan" — the latter, informed by the National Center for Faculty Diversity and Development.

Of the messages and responses I receive regarding my site, the majority are related to the blog section of the website. These entries are snippets and excerpts of the rough drafts in navigation. I write about how I have fallen out of love with writing, about the anxiety of dissertating, and experiencing imposter phenomena. I share these "uncut" versions of myself because academic toxicity extends to the ways we are rewarded for only showing the final product of papers, of ourselves, of our brands. In doing so, we fold into a neoliberal reduction where our lives are treated simply as lines within a curriculum vitae. Thus, while these entries describe my navigation, advice, and 
Journal Committed to Social Change on Race and Ethnicity | Volume 7, Issue 2 | 2021

struggles within academia, they also highlight who am I outside of them- the penchant for listening to podcasts about food, the young adult books I love, the trials of finding a new hobby-a life beyond the work.

\section{Considerations}

In application, maintaining a website requires the deliberation of what platform to use, which incorporates issues of user design and accessibility; questions about purpose and audience; as well as planning for content, consistency, and literal services for hire. The past twenty years has demonstrated a trend of academics utilizing social media and digital platforms to connect to the larger public (Veletsianos \& Kimmons, 2016). A growing number of avenues afford scholars to share their research, whether on publication-based sites like GoogleScholar, ORCID, BePress, ResearchGate, and Academia.edu; social media sites like Twitter, Facebook, Instagram, and TikTok; or developing a personal website through Weebly, Wordpress, and Squarespace. These platforms can and do additionally serve as data points, whether through the analytics and metrics they offer in terms of readership, engagement, and downloads to supporting research as landing pages for project information, supporting recruitment, and data collection. Yet at the same time, maintaining these types of sites are not only costly in terms of labor, time, and potentially finance, but also in terms of mental health. Public engagement can and has led to disproportionate harm to Scholars of Color, especially at the intersections of gender and sexuality, with cyberbullying, doxxing, and harassment (McGlotten, 2016; Noble \& Tynes, 2016). At the same time, public engagement metrics are increasingly valued by academic institutions (Cabrera et al., 
Journal Committed to Social Change on Race and Ethnicity | Volume 7, Issue 2 | 2021

2017), further evidenced through lists like the RHSU Edu-Scholar Public Influence Rankings.

I recognize that in some ways, showcasing a website might look as a recommendation or encouragement for others to create similar platforms, potentially folding into the neoliberal engine of more - more labor, more products, more rankings (see Gonzales \& Núñez, 2014). Yet more is necessary, when considering the ways Communities of Color have not been served through mainstream websites, digital platforms, media outlets, and even the backend algorithms themselves (see Noble, 2018). Thus, the recommendation from this reflection is not for every scholar to create a website or establish their own digital counterspace, but instead consider the ways to best challenge academic gatekeeping and share information. For some, that could be a replication or expansion of a digital site, which is both necessary and welcomed. For others, that could translate into not developing or investing along these lines and instead, considering the ways to build and support the counterspaces and placemaking at their respective universities.

Within these discourses and service, I encourage us to consider and challenge knowledge production: who has it, who holds it, who legitimates it. Existing literature has well-documented the ways Scholars of Color, especially Women of Color are overlooked and not-credited for their intellectual labor (Neimann, 2012; Settles et al., 2021), which is additionally compounded in the ways they take on ghost advising (see Schultheiss, 2018) both in the physical and virtual world. In creating digital counterspaces, I encourage us to extend our citation politics (e.g., \#CiteASista from Williams \& Collier, n.d.) and consider how we credit syllabi, book lists, images, photos, 
Journal Committed to Social Change on Race and Ethnicity | Volume 7, Issue 2 | 2021

and other digital mediums. This too, reflects the deepening network of knowledge outside the traditional peer-reviewed articles, located behind paywalls. An example, within my own site I connect to reading lists from the Asian American Feminist Collective, hyperlink to Black Women's Studies Booklist, and highlight scholars and podcasts with like-minded purposes of creating a digital community of resources and resistance.

Having a website does not come without its tensions and challenges. In 2020, I transitioned into becoming a faculty member. In doing so, I debated fiercely within myself about whether to retain the entries and blog posts of my journey, balancing the gendered, raced perceptions regarding who is allowed to be vulnerable and the lessthan-perfect drafts of ourselves (Neimann, 2012; Pittman, 2010). As seen by its continued existence, which includes a post about the decision, I engage in an act of political refusal. Academic socialization requires not just our disembodiment, but also that we silence our experiences to remain professional, remain the final product of ourselves. In doing so, manifestations of academic toxicity translate into the proverbial rat race and the pressure to perform and produce (Gay, 2004; Gildersleeve et al., 2011; Pelletier et al., 2019), at the expense of our humanity, dignity, and livelihood.

\section{Conclusion}

Challenging academia requires a communal response. As Lilla Watson states, "our liberation is tied to each other." While the institution of academia is rarely if ever a liberatory vessel, I argue that it can be a site of resistance. For many of us, community allows us to navigate and survive the academy (Muhs et al., 2012) — these communities are an act of resistance against neoliberalism, white supremacy, and coloniality. They 
Journal Committed to Social Change on Race and Ethnicity | Volume 7, Issue 2 | 2021

become the buffer that allows us to engage in the liberatory work so many of us believe in, and yet, are targeted for. This collective support is what I refer to as (web)sites of resistance within an institution that celebrates rugged individualism and an academy that encourages productive perfection.

In a given year, the site receives about 10,000 to 15,000 views. I share this number, not as a metric of it being a lot or a little, but rather as a commentary and observation of how people desire this information, community, and resistance - things that are not available unless we proactively build, share, and distribute. Much in the ways the site and myself reflect a work in progress, I humbly offer this praxis in conversation and community with so many because there is space for all our stories and learnings. We have already started to dismantle the knowledge hoarding and in sharing this reflection, I encourage us as a community to continue to challenge, and disrupt the gatekeeping and socialization in which we are all complicit. I look forward to visiting your sites; may we build webs of resistance.

\section{References}

Ahmed, S. (2012). On being included: Racism and diversity in institutional life. Duke University Press.

Ahmed, S. (2021). Complaint! Duke University Press.

Cabrera, D., Vartabedian, B. S., Spinner, R. J., Jordan, B. L., Aase, L. A., \& Timimi, F. K. (2017). More than likes and tweets: Creating social media portfolios for academic promotion and tenure. Journal of Graduate Medical Education, 9(4), 421-425. https://doi.org/10.4300/JGME-D-17-00171.1

Delgado Bernal, D. \& Villalpando, O. (2002). An apartheid of knowledge in academia: The struggle over the "legitimate" knowledge of Faculty of Color. Equity \& Excellence in Education, 35(2), 169-180. http://doi.org/10.1080/713845282

Gay, G. (2004) Navigating marginality en route to the professoriate: graduate students of color learning and living in academia, International Journal of Qualitative Studies in Education, 17(2), 265-288. http://doi.org/10.1080/09518390310001653907

Gildersleeve, R. E., Croom, N. N., \& Vasquez, P. L. (2011). “Am I going crazy?!”: A Critical Race analysis of doctoral education. Equity \& Excellence in Education, 44(1), 93-114. http://doi.org/10.1080/10665684.2011.539472 
Journal Committed to Social Change on Race and Ethnicity | Volume 7, Issue 2 | 2021

Gonzales, L. D. \& Núñez, A. M. (2014). The ranking regime and the production of knowledge: Implications for academia. Education Policy Analysis Archives, 22(31), 1-24.

Harris, C. (2016, September 16). Myth of the independent scholar [Keynote]. University of California Graduate School Equity, Inclusion, Diversity Orientation.

Lee, S. J., Wong, N.-W. A., \& Alvarez, A. N. (2009). The model minority and the perpetual foreigner: Stereotypes of Asian Americans. In N. Tewari \& A. N. Alvarez (Eds.), Asian American psychology: Current perspectives (pp. 69-84). Routledge.

Mac, J., Yi, V., Na, V., Thaviseth, L., Phommasa, M., \& Pheng, L. M. (2021). The SEAAster Scholars Collective: A story of homemaking in academia. Journal of Southeast Asian American Education and Advancement, 16(1), 1-10. http://doi.org/10.7771/2153-8999.1233

McGlotten, S. (2016). Black data. In E. Patrick Johnson (Ed.). No tea, no shade: New writing in Black queer studies (pp. 262-286). Duke University Press.

Muhs, G. G. y, Niemann, Y. F., González, C. G., \& Harris, A. P. (Eds.). (2012). Presumed incompetent: The intersections of race and class for women in academia. University Press of Colorado. https://doi.org/10.2307/j.ctt4cgr3k

National Center for Faculty Diversity and Development. (n.d.). Every semester needs a plan [Webinar]. https://www.facultydiversity.org/webinars/semesterplan21

Neimann, Y. F. (2012), Lessons from the experiences of women of color working in academia. In G. Gutiérrez y Muhs, Y. F. Niemann, C. G. González, \& Angela P. Harris (Eds.) Presumed Incompetent: The Intersections of Race and Class for Women in Academia (pp. 446-500). University Press of Colorado.

Noble, S. U. (2018). Algorithms of oppression: How search engines reinforce racism. New York University Press.

Noble, S. U. \& Tynes, B. (2016). The intersectional internet: Race, sex, class, and culture online. Peter Lang.

Ong, M., Smith, J., M. \& Ko, L. T. (2018). Counterspaces for women of color in STEM higher education: Marginal and central spaces for persistence and success. Journal of Research in Science Teaching, 55(2), 206-245. https://doi.org/10.1002/tea.21417

Patel, L. (2016). Decolonizing educational research: From ownership to answerability. Routledge.

Patrón, O. E., O. J. Flores, and Ø. Medina. 2021. The (unspoken) pact: A composite counternarrative of Latino males in a doctoral program at a predominantly white institution in the Midwest. International Journal of Qualitative Studies in Education, 34 (4), 295-314. https://doi.org/10.1080/09518398.2020.1754490.

Pelletier, K. L., Kottke, J. L., \& Sirotnik, B. W. (2019). The toxic triangle in academia: A case analysis of the emergence and manifestation of toxicity in a public university. Leadership, 15(4), 405-432. https://doi.org/10.1177/1742715018773828

Pittman C. T. (2010). Race and gender oppression in the classroom: The experiences of women Faculty of Color with white male students. Teaching Sociology, 38(3), 183-196. http://doi.org/10.1177/0092055X10370120 
Journal Committed to Social Change on Race and Ethnicity | Volume 7, Issue 2 | 2021

Sanchez, B., Salazar, C., \& Guerra, J. (2020). "I feel like I have to be the whitest version of myself": Experiences of early career Latina higher education administrators. Journal of Diversity in Higher Education. https://doi.org/10.1037/dhe0000267

Sarnecka, B. (2019). The writing workshop: Write more, write better, be happier in academia. (n.p.): Author.

Schultheiss, K. (2018, March 4). Ghost advising. The Chronicle of Higher Education. https://www.chronicle.com/article/ghost-advising/

Settles, I. H., Jones, M. K., Buchanan, N. T., \& Brassel, S. T. (2021) Epistemic exclusion of women faculty and Faculty of Color: Understanding scholar(ly) devaluation as a predictor of turnover intentions. The Journal of Higher Education, online print, http://doi.org/10.1080/00221546.2021.1914494

Stanley, C. (2007). When counternarratives meet master narratives in the journal editorial-review process. Educational Researcher, 36(1), 14-24. http://doi.org/10.3102/0013189X06298008

Steele, T. (2018). Toxicity in the work environment: Retaining staff members of color at a predominantly White institution. College Student Affairs Journal, 36(1), 109123.

Sullivan P.A. (1994). Revising the myth of the independent scholar. In S.B. Reagan, T. Fox \& D. Bleich (Eds.) Writing with: New directions in collaborative teaching, learning, and research (pp. 11-30). SUNY Press.

Tichavakunda, A. A. (2020). Studying Black student life on campus: Toward a theory of Black placemaking in higher education. Urban Education, 1-28. https://doi.org/10.1177/0042085920971354

Veletsianos, G. \& Kimmons, R. (2016). Scholars in an increasingly open and digital world: How do education professors and students use Twitter? The Internet and Higher Education, 30, 1-10. https://doi.org/10.1016/j.iheduc.2016.02.002

Williams, B. M. \& Collier, J. (n.d.). About us [Blog post]. https://citeasista.com/about/

Yao, C.W., Rutt, J., Briscoe, K., Kirshenbaum, A., Knight, M.W., \& Buell, K. J. (2019). Navigating the first year: Transition and adjustment experiences of international students of Color at a predominantly white institution. Journal of College Orientation, Transition and Retention, 26(2), 1-25.

Yosso, T. J. (2006). Critical race counterstories along the Chicana/Chicano educational pipeline. Routledge. 